\title{
AVALIAÇÃO DA RESISTÊNCIA DE MISTURAS DE SOLO RESIDUAL DE BASALTO COM RESÍDUOS DE MICROESFERAS DE VIDRO
}

\author{
A. V. XAVIER, M. L. MENEGOTTO, P. E. G. BOEHL \\ Instituto Federal de Educação, Ciência e Tecnologia do Rio Grande do Norte \\ andressa_vignex@hotmail.com ${ }^{1}$ \\ Artigo submetido em 16/08/2018 e aceito em 26/07/2019 \\ DOI: 10.15628/holos.2019.7634
}

\section{RESUMO}

As microesferas de vidro são materiais abrasivos de granulometria fina, comumente utilizadas em atividades industriais para a limpeza e o polimento das peças metálicas. Após a sua utilização, geralmente, são dispostas em aterros de resíduos industriais. O presente estudo buscou uma alternativa de reaproveitamento deste material, realizando uma avaliação do desempenho mecânico de um solo residual de basalto após a adição de diferentes teores de resíduos de microesferas de vidro. Inicialmente, foram realizados ensaios de caracterização das microesferas de vidro e as diversas misturas foram submetidas aos ensaios de compactação, de cisalhamento direto e de índice de suporte Califórnia (ISC). Concluiu-se que o resíduo não atua como um agente na melhoria do solo, pois de maneira geral, as resistências das misturas foram inferiores em relação às determinadas para o solo puro e resíduo puro. Entretanto, as misturas apresentaram ângulos de atrito interno superiores ao do solo puro, sendo o maior valor apresentado pela mistura com teor de resíduos de $20 \%$. No ensaio de ISC, a mistura que apresentou melhor resultado, em relação ao resíduo puro, foi a com $10 \%$ de microesferas de vidro.

PALAVRAS-CHAVE: Resistência ao Cisalhamento, Ensaio de Compactação, Índice de Suporte Califórnia.

\section{EVALUATION OF STRENGTH OF MIXTURES OF BASALT RESIDUAL SOIL WITH GLASS MICROSPHERES WASTE}

\begin{abstract}
The glass microspheres are abrasive materials of fine particles, commonly used in industrial activities for cleaning and polishing of metal parts. After your use, generally, are arranged in landfills of industrial waste. This paper proposes an alternative to reuse this material performing an evaluation of mechanical performance of a basalt residual soil after the addition of different glass microspheres waste contents. Initially, were carried out characterization tests of the glass microspheres and the mixtures were submitted to compaction, direct shear and
\end{abstract}

California Bearing Ratio (CBR) tests. It was noted that the residue does not act in soil improvement, because, in general, the resistance of mixtures were inferior to determined for soil pure and waste pure. However, mixtures showed higher internal friction angles than pure soil, being the highest value displayed by mixing with waste content of $20 \%$. In the ISC test, the mixture that showed better result, compared to pure waste, was with $10 \%$ glass microspheres.

KEYWORDS: Shear Strength, Compaction Test, California Bearing Ratio. 


\section{INTRODUÇÃO}

Um meio bastante promissor, proposto como alternativa de reciclagem ou reuso de resíduos industriais, é o desenvolvimento de pesquisas voltadas para a reutilização em diversas áreas, dentre elas, o aproveitamento na construção civil. Segundo a NBR 10004 (ABNT, 2004), que trata da classificação dos resíduos sólidos, pode-se destacar que os resíduos de microesfera de vidro, objeto do estudo, enquadram-se na Classe II B, a qual representa os resíduos sólidos não perigosos e inertes.

Por assim estarem classificados, é possível considerar o uso das microesferas na construção civil como material de melhoramento de solo, por exemplo, para a aplicação em serviços de pavimentação, tendo em vista que em algumas regiões muitas vezes obras de infraestrutura acabam se tornando onerosas ou até inviáveis pela ausência de material resistente e que possa atender suas demandas estruturais (MOREIRA, 2018).

Além disso, obras de infraestrutura são uma das principais atividades dependentes da extração de matéria prima natural para o seu desenvolvimento. A maior parte dos processos necessitam de elevados volumes de matéria prima e, muitas vezes, os impactos gerados durante a extração destes materiais são irreparáveis. Em virtude deste passivo, a busca por alternativas de reuso de resíduos faz-se necessária para inibir e minimizar a ocorrência de impactos ambientais (SULUGURU, 2017).

No entanto, o uso de materiais alternativos é condicionado pela qualidade do produto final (mistura). No caso das misturas com solo, é preciso analisar se os parâmetros de resistência são suficientemente relevantes para atender às especificações técnicas da obra em que se busca utilizar este tipo de matéria prima.

A prática do reuso de resíduos em misturas com solo é bastante difusa no meio cientifico e envolve estudos com os mais variados tipos de matéria prima, com características distintas, como no caso de Ahmed et al. (2011) que avaliou misturas de solo com resíduos de gesso, ou Kafodya et al. (2018) que estou misturas de solo-fibra, e também Wei et al. (2018) que desenvolveu análises de misturas solo com fibra e cal, e Machado et al. (2012) que avaliou as propriedades da mistura solo-grits, etc.

O estudo desenvolvido, além de trazer contribuições à análise do comportamento geotécnico do solo regional, é de grande importância na esfera ambiental por propor a reciclagem de um resíduo industrial. Além disso, consequentemente, é efetivo na contribuição para a redução de impactos, dentre eles, a diminuição do volume de material disposto em aterros industriais, a economia de energia e a redução da exploração dos recursos naturais (SILVA, 2016).

Para tanto, o presente estudo realizou uma análise geotécnica do incremento de resíduos de microesferas de vidro em um solo residual de basalto, onde foi realizada a caracterização dos resíduos de microesferas de vidro, bem como, determinada a resistência ao cisalhamento e o Índice de Suporte Califórnia das misturas com diferentes teores de resíduo, para fins de comparação com os parâmetros apresentados pelo solo puro e o resíduo puro. 


\section{MATERIAIS E MÉTODOS}

\section{Caracterização e coleta da amostra de solo local}

A região oeste do estado de Santa Catarina, onde se localiza o Município de Chapecó, possui afloramento de rochas da Formação Serra Geral, do Grupo São Bento, predominando rochas vulcânicas efusivas representadas por uma sucessão de derrames que cobrem cerca de $50 \%$ da superfície do estado. Pode-se dar ênfase à sequência básica, a qual se constitui de basaltos de coloração cinza a negra com intercalações de arenitos, e também para a sequência ácida representada por riodacitos a riolitos, de matriz vitrofírica contendo pórfiros de feldspato (SCHEIBE, 1986). A evolução destes maciços rochosos resulta em solos residuais com elevado teor de cálcio e magnésio, de textura argilosa e coloração marrom para vermelha (DIEMER et al., 2008).

Menegotto et al. (2016) realizaram a caracterização geotécnica do solo da Área Experimental da Universidade Federal da Fronteira Sul (UFFS) - Campus Chapecó. Essa área localiza-se nas coordenadas geográficas 270 07' 07,9" S e 52 42' 25,7" W e apresenta uma altitude de 603 m em relação ao nível do mar. Foram determinados o teor de umidade natural (w), a massa específica dos sólidos $\left(\rho_{s}\right)$, o limite de liquidez (LL), limite de plasticidade (LP), o índice de plasticidade (IP) e a composição granulométrica (Tabela 1). A partir desses resultados o solo foi classificado pelo Sistema Unificado como $\mathrm{MH}$, que corresponde a um silte de alta plasticidade, e pelo Sistema Rodoviário como A-7-5. O índice de atividade apresentou um valor de 0,17 , indicando a presença de minerais argilosos inativos.

Tabela 1: Caracterização do Solo da Área Experimental da UFFS - Campus Chapecó.

\begin{tabular}{ccccccccc}
\hline $\begin{array}{c}\text { Prof. } \\
(\mathrm{m})\end{array}$ & $\begin{array}{c}\mathrm{w} \\
(\%)\end{array}$ & $\begin{array}{c}\rho_{\mathrm{s}} \\
\left(\mathrm{g} . \mathrm{cm}^{-3}\right)\end{array}$ & $\begin{array}{c}\text { Argila } \\
(\%)\end{array}$ & $\begin{array}{c}\text { Silte } \\
(\%)\end{array}$ & $\begin{array}{c}\text { Areia } \\
(\%)\end{array}$ & $\begin{array}{c}\mathrm{LL} \\
(\%)\end{array}$ & $\begin{array}{c}\mathrm{LP} \\
(\%)\end{array}$ & $\begin{array}{c}\mathrm{IP} \\
(\%)\end{array}$ \\
\hline 0,5 & 29,3 & 2,757 & 79 & 13 & 8 & 53,3 & 39,9 & 13,4 \\
\hline \multicolumn{8}{c}{ Fonte: Menegotto et al. (2016). }
\end{tabular}

A amostra de solo utilizada nos ensaios do presente trabalho também foi coletada na Área Experimental da UFFS - Campus Chapecó, em uma cava de área de aproximadamente 1,5 $\mathrm{m}^{2}$ e 0,6 $\mathrm{m}$ de profundidade. Posteriormente, a amostra foi conduzida ao Laboratório de Geotecnia Ambiental do campus, deixada secar ao ar livre e, para melhor homogeneização, foi passada em uma peneira com malha de $2 \mathrm{~mm}$ de abertura, por se tratar predominantemente de material fino.

\section{Coleta e caracterização da amostra de resíduos de microesferas de vidro}

Os resíduos de microesferas de vidro foram coletados em uma Indústria Metalúrgica localizada na cidade de Chapecó/SC. Tais resíduos são provenientes do processo de jateamento nas peças de aço inox. Posteriormente ao lançamento do material contra as peças, a parte residual é encaminhada com o auxílio de uma esteira para um filtro manga onde ocorre sua sedimentação e, posteriormente, a deposição em uma bolsa coletora utilizada como instrumento de armazenagem temporária do resíduo, até que o mesmo seja encaminhado para um aterro industrial. 
Os resíduos foram caracterizados através da realização de ensaios de granulometria, massa específica dos sólidos e limites de consistência. Para a realização da análise granulométrica os resíduos foram submetidos a um processo de peneiramento conforme a metodologia prescrita pelo DNER-ME 058 (1994). Foi tomada uma porção de aproximadamente $500 \mathrm{~g}$ da amostra de microesferas de vidro, a qual passou por um conjunto de peneiras de diferentes aberturas, conforme proposto na norma.

O ensaio para a determinação da massa específica dos sólidos foi adaptado da NBR 6508 (ABNT, 1983). O procedimento consistiu em dispor uma amostra de $60 \mathrm{~g}$ de resíduo em um picnômetro de calibração pré-estabelecida e posteriormente preencher metade do volume do recipiente com álcool etílico $90 \%$. O conjunto foi submetido a uma pressão de vácuo para a eliminação do ar no interior das partículas de microesfera por cerca de 20 minutos. Após o fim deste processo, o picnômetro teve seu volume total preenchido por álcool, para que o conjunto pudesse ser submetido a pesagem para a temperatura de $20^{\circ} \mathrm{C}$. O ensaio foi realizado em triplicata.

O ensaio para a determinação do limite de liquidez fora realizado de acordo com a normativa NBR 6459 (ABNT, 1984), através da utilização do aparelho de Casagrande. Parte do resíduo preparado previamente foi transferido para a concha do equipamento, onde ocorreu a divisão em duas partes, para que fosse aberta uma ranhura, com o auxílio de um cinzel. Imediatamente, foi coletada uma amostra da concha para a determinação da umidade. Logo após, a concha foi golpeada contra a base do aparelho de Casagrande até que as bordas da ranhura se unissem. Este procedimento foi repetido por cinco vezes, no entanto, o ensaio não pôde ser concluído em virtude de que a composição do resíduo não permitiu que a ranhura permanecesse aberta.

O ensaio para a determinação do limite de plasticidade foi realizado com o auxílio das diretrizes fornecidas pela NBR 7180 (ABNT, 1984). Para a execução do ensaio, uma pequena porção de amostra do resíduo foi tomada e umedecida, até que esta pudesse rolar em uma placa de vidro até formar um pequeno cilindro de dimensões de $3 \mathrm{~mm}$ de diâmetro e 12 a $15 \mathrm{~cm}$ de comprimento. No entanto, não foi possível evitar que o cilindro fissurasse, por isso o ensaio foi interrompido.

\section{Preparação e ensaios das misturas solo-resíduo}

As misturas de solo com resíduo de microesferas de vidro foram preparadas conforme as composições de $0,10,20,30,40$ e 100\% de resíduo. Esta composição é referente aos teores de proporção em massa seca (Equação 1).

$$
\mu=\frac{\mathrm{M}_{\mathrm{MS}}}{\mathrm{M}_{\mathrm{MS}}+\mathrm{M}_{\mathrm{SS}}} \times 100
$$

Em que: $\mu=$ teor de resíduos de microesferas; $M_{M S}=$ massa de microesfera de vidro seca; $M_{s s}=$ massa de solo seco.

Conhecendo o teor de umidade do solo e dos resíduos, a porção tomada para a realização de cada ensaio era previamente confinada em sacos plásticos com a finalidade de manter a 
quantidade de água presente nos materiais. Posteriormente, para o preparo de cada mistura, retirava-se a quantidade necessária de amostra e os dois materiais eram homogeneizados até formarem a mistura que se pretendia analisar.

\section{Ensaio de compactação}

O Ensaio de Compactação de Proctor foi realizado de acordo com a NBR 7182 (ABNT, 1986). Para a realização do ensaio, utilizou-se o cilindro de Proctor em conjunto com a base e o colarinho, onde as misturas foram compactadas em três camadas empregando-se a energia normal. $O$ ensaio foi realizado com reuso de material e para cada mistura foram ensaiados, no mínimo, cinco pontos com diferentes teores de umidade.

A curva de compactação do solo foi traçada com os valores de peso específico seco versus teor de umidade da amostra compactada. A determinação do peso específico seco máximo e o teor de umidade ótimo correspondente foi realizada a partir da interpretação de cada curva. Com estes valores foi possível realizar a moldagem dos corpos de prova, para a realização dos ensaios de cisalhamento direto e de Índice de Suporte Califórnia (ISC).

\section{Ensaio de cisalhamento direto}

Para a realização do ensaio de cisalhamento direto, os corpos de prova foram preparados por meio de compactação estática, utilizando uma prensa de ISC (Índice de Suporte Califórnia). Conhecendo as dimensões da célula bipartida (50 ×50 × $20 \mathrm{~mm})$, a massa específica seca máxima e o teor de umidade ótimo, foi possível calcular a massa de solo a ser colocada no recipiente em que, ao final da compactação estática, a amostra possuísse um volume tal que a massa de solo seco dividida por este volume, resultasse na massa específica seca máxima. Também, foi determinada a quantidade de água necessária na amostra para que fosse possível obter o teor de umidade ótimo referente à cada composição de mistura.

O equipamento eletrônico utilizado para a realização do ensaio de cisalhamento direto é da marca Pavitest. Tal equipamento é controlado por meio de software específico e possui dois sensores para medição de deslocamentos lineares (LVDTs), os quais medem deslocamento vertical e horizontal. Além disso, possui uma célula de carga para a medição da força de cisalhamento. A velocidade de cisalhamento adotada para a realização dos ensaios foi de $0,020 \mathrm{~mm} / \mathrm{min}$, os quais ocorreram até a condição de deslocamento máximo de $6,0 \mathrm{~mm}$. As tensões normais adotadas nos ensaios foram de 50, 100 e $200 \mathrm{kPa}$.

Com a realização dos ensaios de cisalhamento direto foram obtidas as curvas de tensão cisalhante e deslocamento vertical versus deslocamento horizontal, nas diferentes condições de tensão normal e teores de resíduo de microesferas de vidro. A partir da interpretação destas curvas foi possível determinar a tensão cisalhante na ruptura. Conhecendo as tensões de cisalhamento máximas para cada condição de tensão normal, foi possível traçar as envoltórias de resistência, utilizando o critério de Mohr-Coulomb. 


\section{Ensaio de expansão e Índice de Suporte Califórnia}

A expansão de um solo argiloso consiste em sua variação volumétrica desencadeada a partir da presença de água entre seus vazios. A intensidade deste desarranjo estrutural está intimamente ligada com as características dos argilominerais presentes no solo, sua porosidade, a distribuição das partículas de argila, etc. Solos expansivos são capazes de causar instabilidade e uma série de anomalias em obras de engenharia e, por isso, a avaliação deste parâmetro é fundamental para o desenvolvimento de um projeto seguro e coerente (FERREIRA et al., 2017)

O ensaio para a determinação do Índice de Suporte Califórnia, além de determinar a porcentagem de expansão do solo, é responsável por avaliar a capacidade de suporte de carga de cada camada de pavimento. O resultado do ensaio consiste na definição de um índice que deverá ser comparado às normativas vigentes que regem os serviços de pavimentação e, a partir daí, indicará se o solo poderá ou não ser utilizado como base, sub-base ou subleito de pavimentos. (MALANCONI, 2013)

O ensaio para a determinação do Índice de Suporte Califórnia foi realizado a partir dos procedimentos prescritos pela NBR 9895 (ABNT, 1987). Tal ensaio subdividiu-se em três etapas: moldagem, expansão e penetração. Para a execução da moldagem foi empregada a energia de compactação de Proctor normal. Esta etapa foi realizada com os valores de teor de umidade ótimo e massa específica seca máxima previamente obtidos nos ensaios de compactação.

Para o desenvolvimento do ensaio de expansão foi incorporado em cada cilindro sobre a superfície dos corpos de prova a haste de expansão e, sobrepondo-a, os discos anelares, cujo peso totaliza $4540 \pm 20 \mathrm{~g}$. Posteriormente, o porta-extensômetro foi encaixado na borda superior dos cilindros. Neste momento, os extensômetros foram inseridos nos porta-extensômetro e ajustados até atingir a superfície das hastes de expansão. Os corpos de prova ensaiados permaneceram submersos durante quatro dias. A determinação da expansão foi realizada a partir da diferença de leitura no extensômetro entre o primeiro e último dia de medição, dividida pela altura inicial da amostra, sendo expressa em porcentagem.

Por fim, após os quatro dias de submersão, cada corpo de prova foi retirado para ser submetido ao ensaio de penetração. Neste ensaio, os cilindros foram inseridos numa prensa de ISC (Índice de Suporte Califórnia) até que o pistão de penetração fosse assentado no corpo de prova, pela aplicação de uma carga. Uma série de leituras foram efetuadas em um intervalo de tempo préestabelecido pela norma, a fim de medir a penetração do pistão (em milímetros) em determinados instantes.

\section{RESULTADOS E DISCUSSÃO}

\section{Caracterização do resíduo}

A caracterização geotécnica dos resíduos de microesferas de vidro foi realizada por meio de ensaios de análise granulométrica, determinação dos limites de consistência e da massa específica 
dos sólidos. Na Figura 1 é possível analisar a distribuição granulométrica do resíduo, a qual está representada em conjunto com a distribuição granulométrica do solo residual de basalto determinada por Menegotto et al. (2016).

O solo possui característica de material fino, com fração predominante de partículas do tamanho de argila. Por outro lado, o resíduo possui característica de material granular, por apresentar textura semelhante à de solos arenosos finos conforme propõe a classificação da NBR 6502 (ABNT, 1995), com 78\% das partículas de tamanho entre 0,06 a 0,2 mm, e não possuir propriedades de plasticidade.

$\mathrm{Na}$ Tabela 2 encontra-se um resumo dos resultados dos ensaios de caracterização do resíduo. De acordo com o Sistema Unificado esse material foi classificado como SP, que corresponde a uma areia mal graduada, e pelo Sistema Rodoviário como A-4.

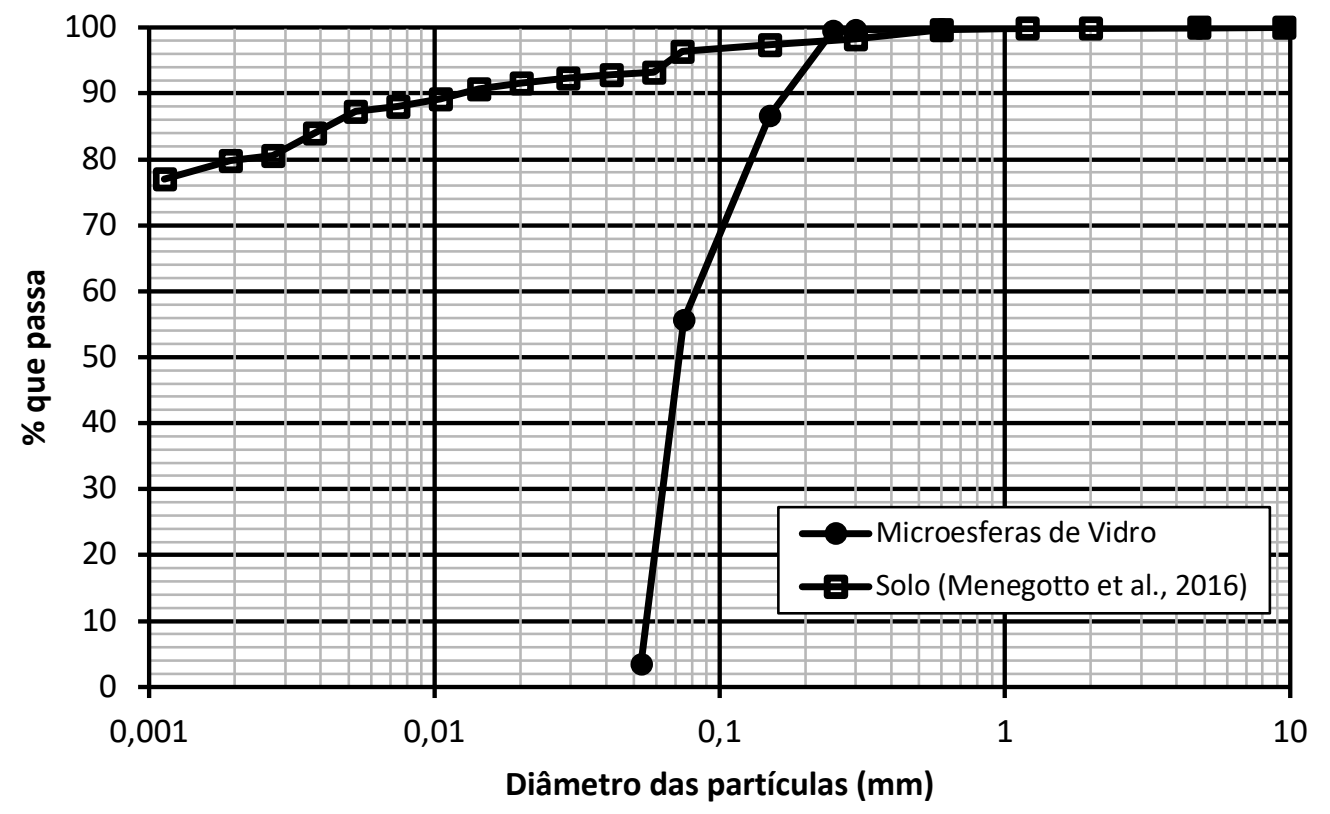

Figura 1: Curva de distribuição granulométrica do solo e dos resíduos de microesferas de vidro.

Tabela 2: Resumo dos parâmetros de caracterização do resíduo de microesferas de vidro.

\begin{tabular}{ccccccc}
\hline $\begin{array}{c}\text { Argila } \\
(\%)\end{array}$ & $\begin{array}{c}\text { Silte } \\
(\%)\end{array}$ & $\begin{array}{c}\text { Areia } \\
(\%)\end{array}$ & $\begin{array}{c}\mathrm{LL} \\
(\%)\end{array}$ & $\begin{array}{c}\mathrm{LP} \\
(\%)\end{array}$ & $\begin{array}{c}\text { IP } \\
(\%)\end{array}$ & $\begin{array}{c}\rho_{\mathrm{s}} \\
\left(\mathrm{g} . \mathrm{cm}^{-3}\right)\end{array}$ \\
\hline- & 22 & 78 & NP & NP & NP & 2,49 \\
\hline
\end{tabular}

\section{Ensaio de compactação}

As curvas de compactação determinadas para as misturas com as porcentagens de resíduo de $10 \%, 20 \%, 30 \%, 40 \%$, para o solo puro (0\%) e para o resíduo puro (100\%), estão apresentadas na Figura 2. Já na Tabela 3 é possível observar os valores do teor de umidade ótimo e da massa 
específica seca máxima para todas as composições analisadas. Diante dos resultados, nota-se que o acréscimo de microesferas de vidro ao solo provoca um aumento na massa específica seca máxima. Por outro lado, a compactação do resíduo puro é prejudicada devido ao material ser muito uniforme, com suas partículas não conseguindo preencher os vazios, o que causa uma redução na massa específica seca máxima em relação às demais composições. Quanto ao teor de umidade ótimo, o valor diminui com o aumento do teor de resíduo nas misturas, uma vez que as microesferas de vidro apresentam características de material granular.

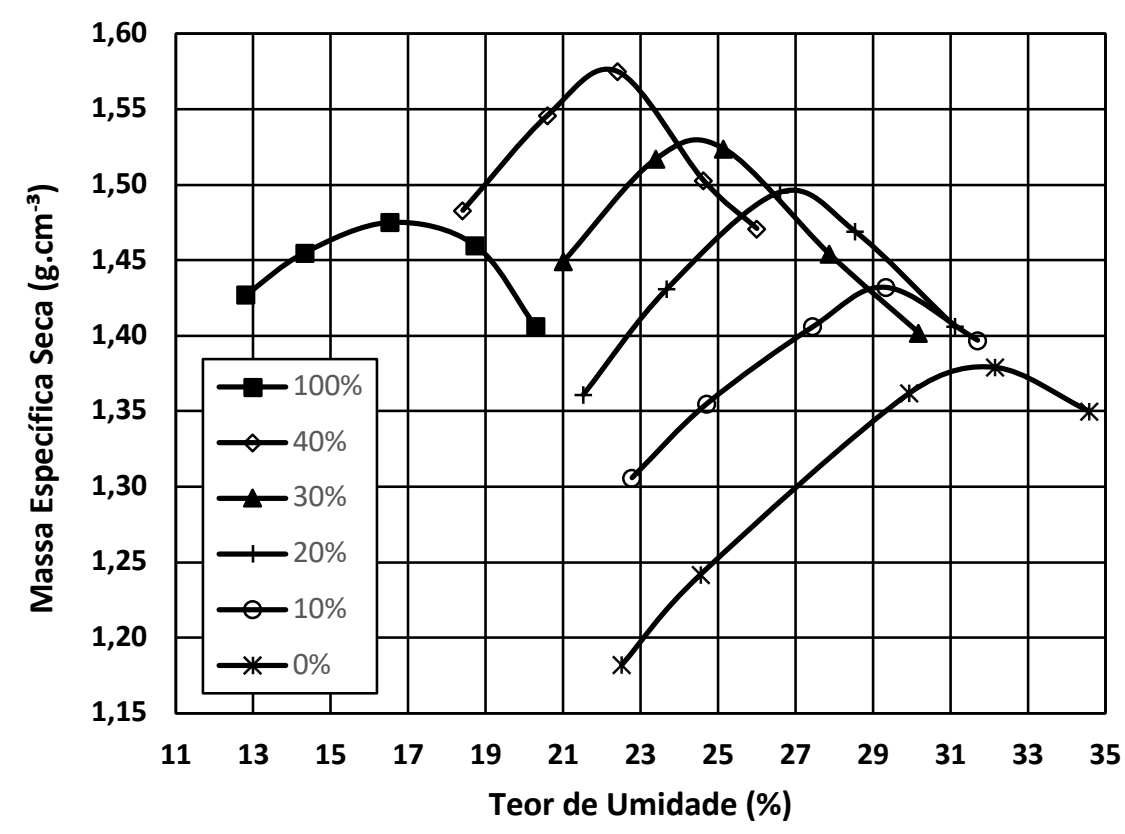

Figura 2: Curvas de compactação das amostras com diferentes teores de resíduos.

Tabela 3: Massa específica seca máxima e teor de umidade ótimo para as amostras ensaiadas com diferentes teores de resíduos, solo puro e resíduo puro.

\begin{tabular}{ccc}
\hline $\begin{array}{c}\text { Teor de microesferas } \\
\text { de vidro (\%) }\end{array}$ & $\begin{array}{c}\boldsymbol{\rho}_{\text {d máx }} \\
\left(\mathbf{g} \cdot \mathbf{c m}^{-3} \mathbf{)}\right.\end{array}$ & $\begin{array}{c}\mathbf{W}_{\text {ót }} \\
\mathbf{( \% )}\end{array}$ \\
\hline 0 & 1,380 & 31,9 \\
\hline 10 & 1,432 & 29,2 \\
\hline 20 & 1,488 & 27,0 \\
\hline 30 & 1,528 & 24,5 \\
\hline 40 & 1,577 & 22,3 \\
\hline 100 & 1,475 & 16,8 \\
\hline
\end{tabular}

Ensaio de cisalhamento direto

Durante a execução dos ensaios de cisalhamento direto, o comportamento dos corpos de prova é determinado através das curvas tensão de cisalhamento e deslocamento vertical versus 
deslocamento horizontal. A título de exemplificação, as curvas determinadas para o solo puro e as porcentagens de 20\%, 40\% e 100\% de resíduo, podem ser visualizadas nas Figuras de 3 a 6 , respectivamente. Para as leituras de deslocamento vertical, os valores negativos correspondem à dilatação da amostra ao longo do ensaio e os valores positivos representam a redução de volume durante o cisalhamento.

Na Figura 3 é possível observar o comportamento da amostra de solo puro durante o cisalhamento. Os valores máximos de tensão cisalhante determinados para as tensões normais de 50, 100 e $200 \mathrm{kPa}$ foram de 50, 63 e 99 kPa, respectivamente. Para as três tensões normais ensaiadas não foi possível antever um pico bem definido de resistência ao cisalhamento. As tensões cisalhantes não se estabilizaram ao longo do deslocamento, houve variações até o último milímetro do ensaio, principalmente na tensão de $200 \mathrm{kPa}$, que variou exponencialmente. Quanto ao deslocamento vertical, houve redução de volume nos três níveis de tensões normais aplicados, no entanto, a tensão de $100 \mathrm{kPa}$ apresentou a menor redução de volume se comparada às outras duas.
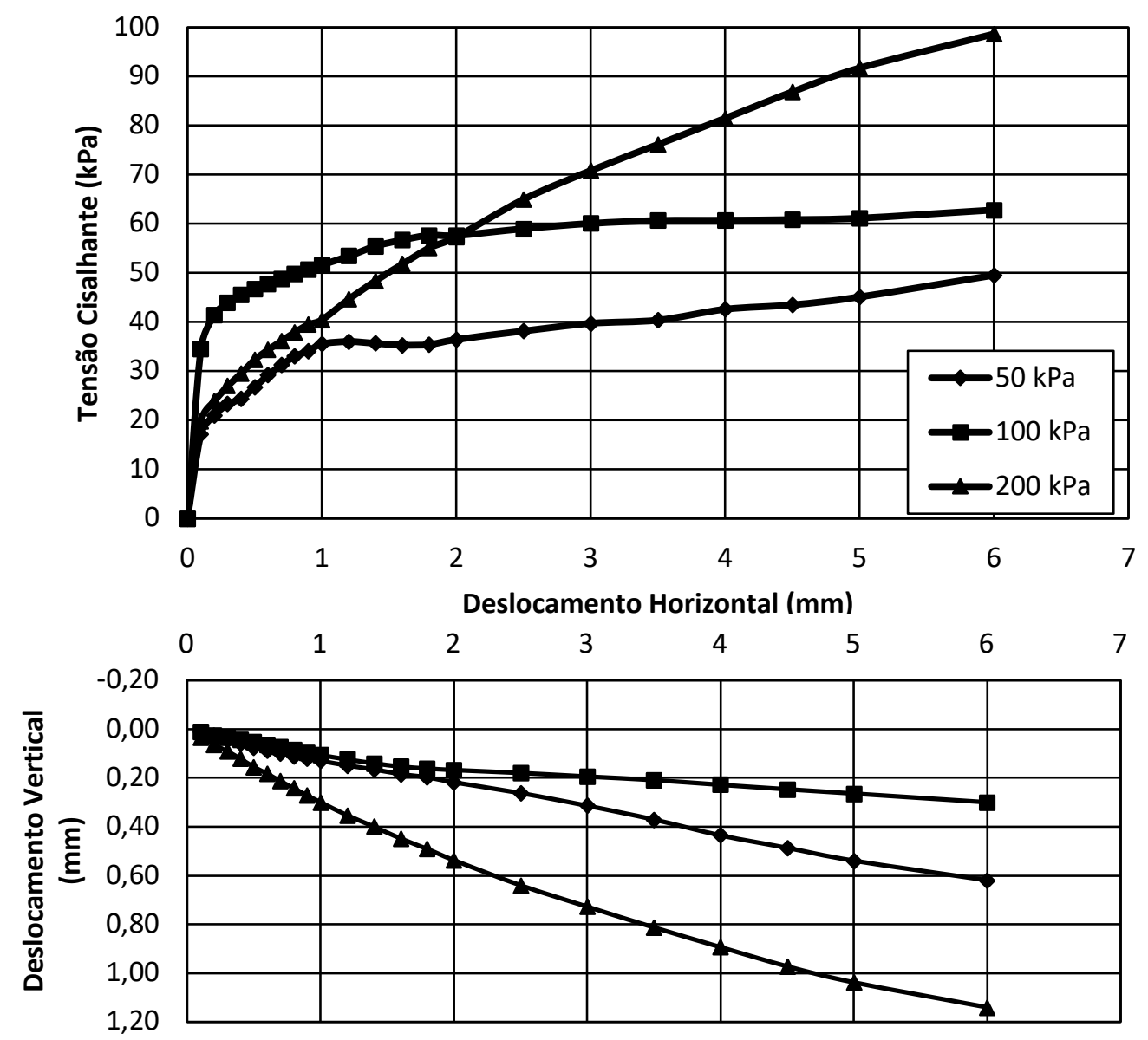

Figura 3: Resultado do ensaio de cisalhamento direto para as amostras de solo puro.

Conforme a Figura 4, é possível verificar que a mistura com teor de $20 \%$ de resíduo de microesferas de vidro apresentou resistência ao cisalhamento superior ao solo puro para tensão normal de $200 \mathrm{kPa}$, com altas resistências já a partir do deslocamento de $3 \mathrm{~mm}$. Os valores máximos de tensão foram de 43, 59 e 114 kPa para as respectivas tensões de 50, 100 e 200 kPa. Houve 
redução de volume durante o cisalhamento das três amostras, que se deu de acordo com intensidade da carga aplicada, ou seja, para a tensão de $50 \mathrm{kPa}$ a amostra apresentou menor redução e para a tensão de $200 \mathrm{kPa}$ a redução de volume foi cerca de cinco vezes maior.
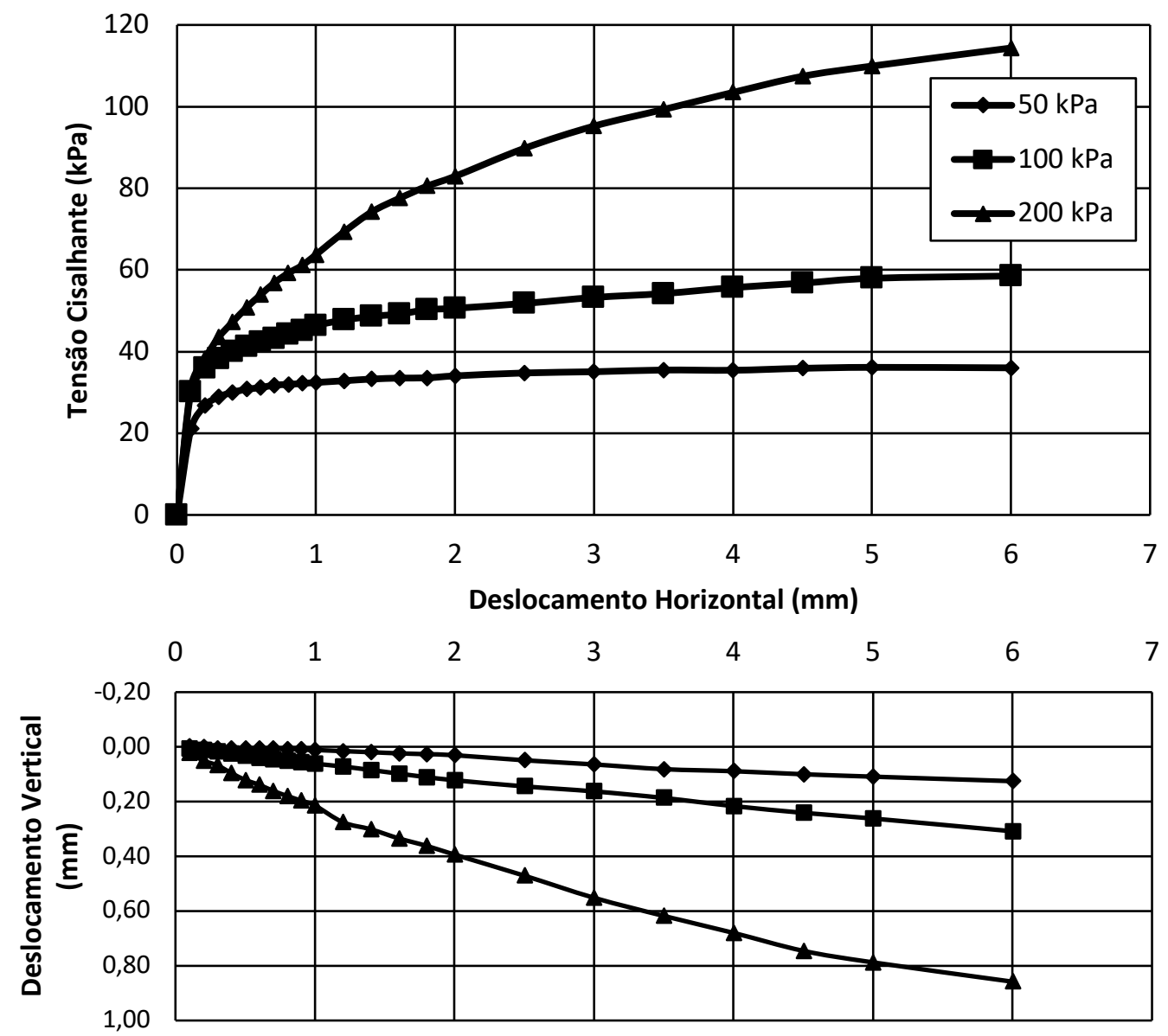

Figura 4: Resultado do ensaio de cisalhamento direto para as amostras com $20 \%$ de resíduo.

Na Figura 5, é possível analisar as variações sofridas pelos corpos de prova ensaiados com a composição de $40 \%$ de resíduo. As tensões máximas cisalhantes foram de 24, 49 e $106 \mathrm{kPa}$ para as tensões normais de 50, 100 e $200 \mathrm{kPa}$, respectivamente. O comportamento observado é o de material dúctil. Quanto à deformação vertical, para a tensão de $50 \mathrm{kPa}$ a amostra apresentou comportamento de dilatação até os $4 \mathrm{~mm}$ e a partir deste valor sofreu redução de volume, diferentemente dos resultados apresentados por as demais misturas. 

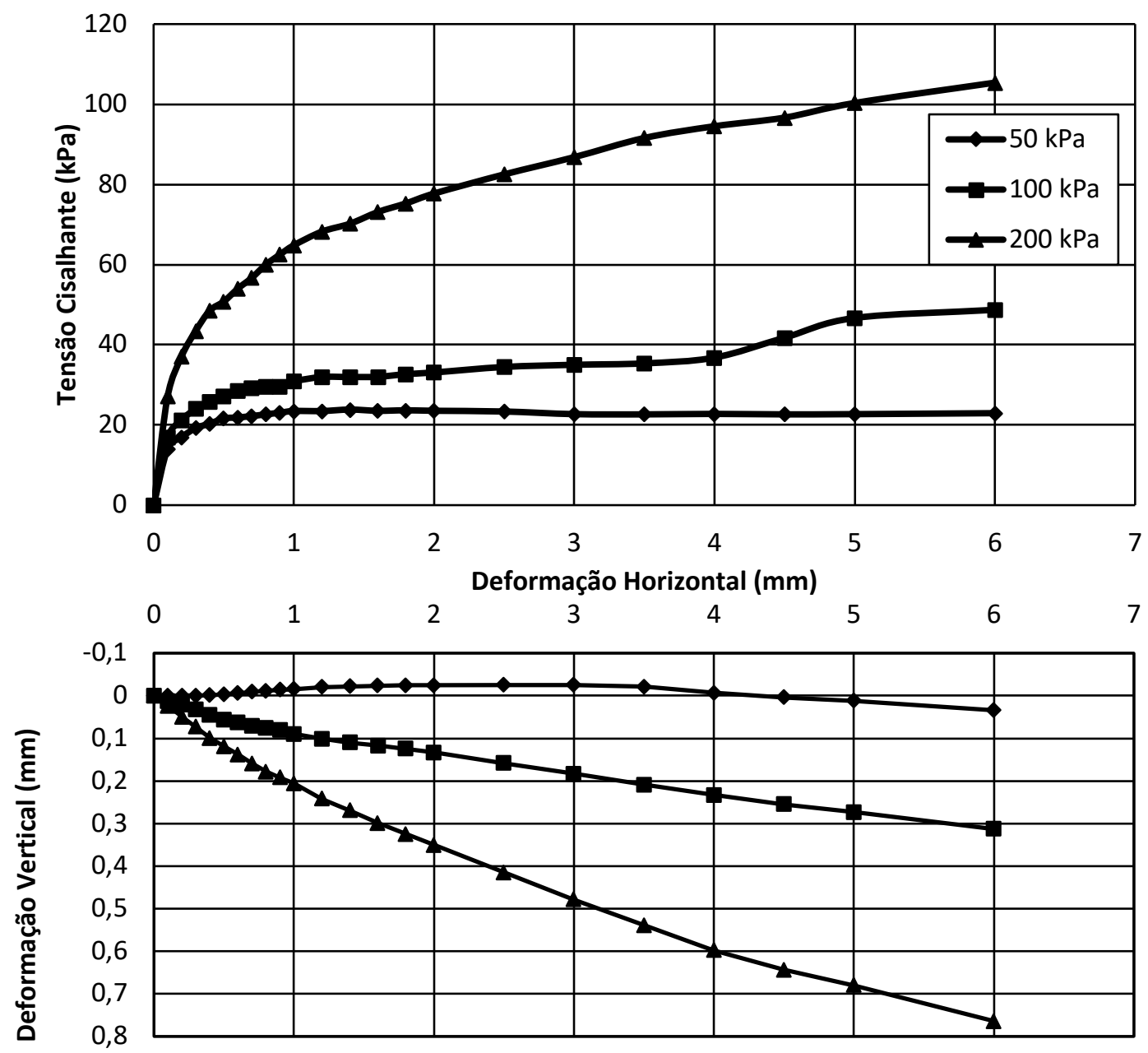

Figura 5: Resultado do ensaio de cisalhamento direto para as amostras com $40 \%$ de resíduo.

A Figura 6 denota o comportamento da amostra composta apenas de resíduo. As tensões de cisalhamento máximas determinadas foram de 22, 50 e $101 \mathrm{kPa}$ para as tensões normais de 50, 100 e $200 \mathrm{kPa}$, respectivamente. Também não foram obtidos picos de resistência bem definidos e houve a estabilização da tensão cisalhante ao longo do deslocamento para a tensão de $50 \mathrm{kPa}$. Em relação ao comportamento das amostras no que diz respeito à variação de volume, todas apresentaram comportamento redutivo. Para a tensão de $50 \mathrm{kPa}$, não foi possível medir o deslocamento vertical apresentado pela amostra durante o ensaio.

Em geral, pode-se destacar que os corpos de prova sofreram redução no seu volume, com destaque para as misturas submetidas às tensões normais maiores (200 kPa), que apresentaram os valores mais redutivos. No caso das curvas de tensão cisalhante versus deslocamento horizontal, pode-se destacar que não houve picos de tensão bem definidos. Este comportamento de redução do volume e ausência de valores de pico de tensão de cisalhamento assemelha-se ao de areias fofas ou argilas normalmente adensadas. 

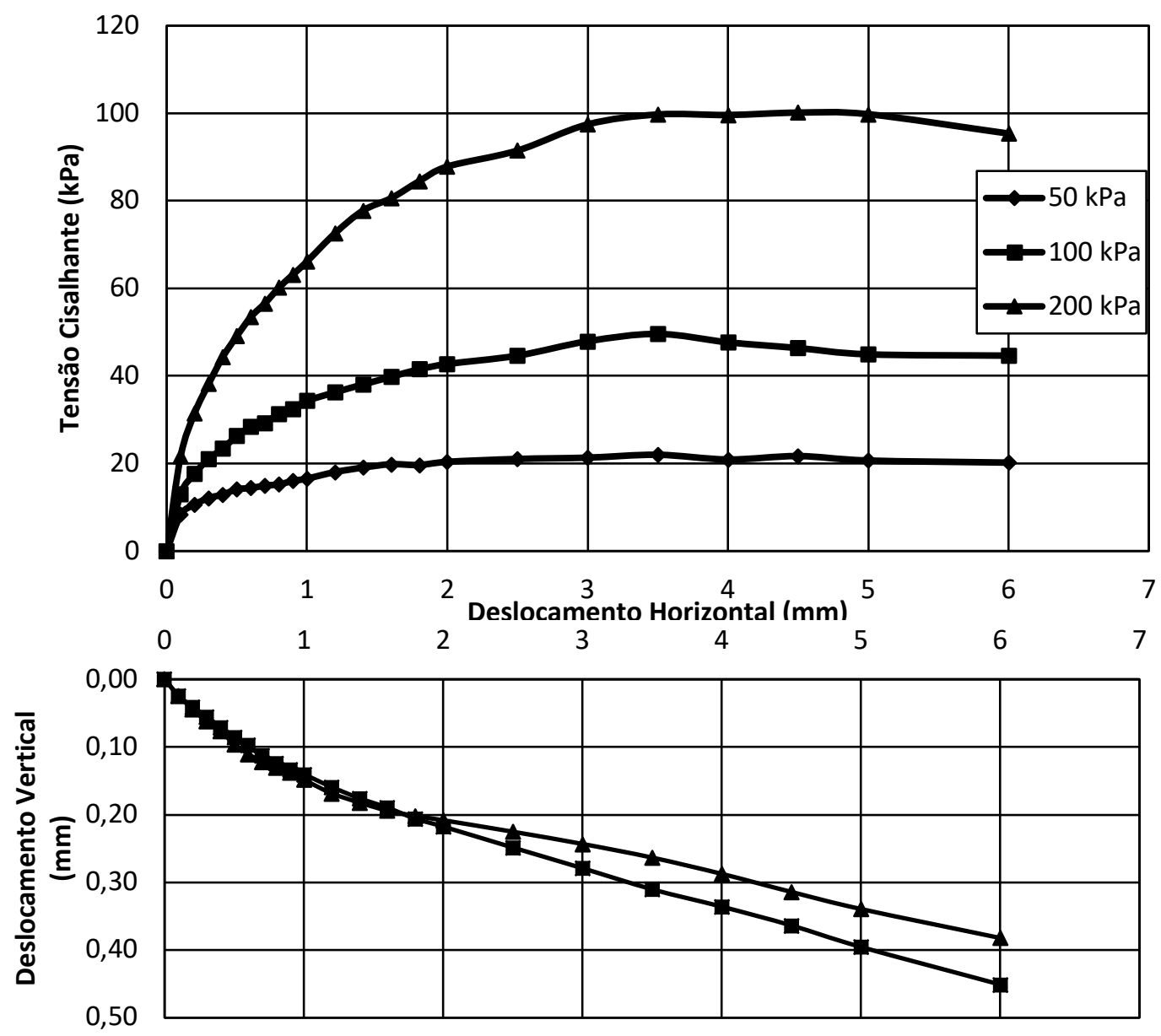

Figura 6: Resultado do ensaio de cisalhamento direto para as amostras de resíduo puro.

Em relação aos ensaios realizados com o solo puro e resíduo puro, é importante destacar o comportamento distinto que cada um adquiriu tanto ao decorrer do deslocamento da ordem de 3 a $4 \mathrm{~mm}$, quanto ao acréscimo de carga. O solo puro atingiu tensões de cisalhamento máximas ao final do deslocamento máximo do ensaio, enquanto para os resíduos de microesferas as tensões máximas foram registradas ao longo do deslocamento e, posteriormente a isso, praticamente estabilizaram-se até o final do ensaio. Em relação ao deslocamento vertical dos corpos de prova, a amostra de solo puro registrou maior redução de volume quando submetida a maior tensão normal. Para a tensão de 100 kPa, o resíduo apresentou maior compressão.

As Figuras 7, 8 e 9 apresentam uma síntese das tensões de cisalhamento máximas obtidas para o solo puro, resíduo puro e as demais misturas em cada uma das três tensões normais ensaiadas. Nas três figuras, a linha pontilhada que interliga o valor máximo de resistência ao cisalhamento do solo puro ao de resíduo puro representa a contribuição dos mecanismos de cisalhamento interno para a resistência ao cisalhamento das misturas. As resistências acima da linha indicam a contribuição dos resíduos como reforço para o aumento da resistência, conforme a metodologia proposta por Zornberg et al. (2004). 
Apenas as misturas de 20 e $40 \%$ de resíduo quando submetidas a tensões normais elevadas (200 kPa) poderiam contribuir para a melhoria do solo analisado. Quanto às demais tensões normais, nota-se que houve uma redução da tensão de cisalhamento máximo com a adição do resíduo ao solo.

O que se pode ponderar é que a resistência do resíduo está condicionada a uma série de fatores que variam desde a composição química, o formato, tamanho e graduação das partículas, as tensões normais aplicadas, etc. No caso das microesferas de vidro, os fatores que contribuem para a redução da resistência do resíduo são a granulometria muito uniforme e o mesmo ter sido submetido ao processo de jateamento, que promove a quebra das partículas e alterações em seu formato podendo torná-las menos resistente.

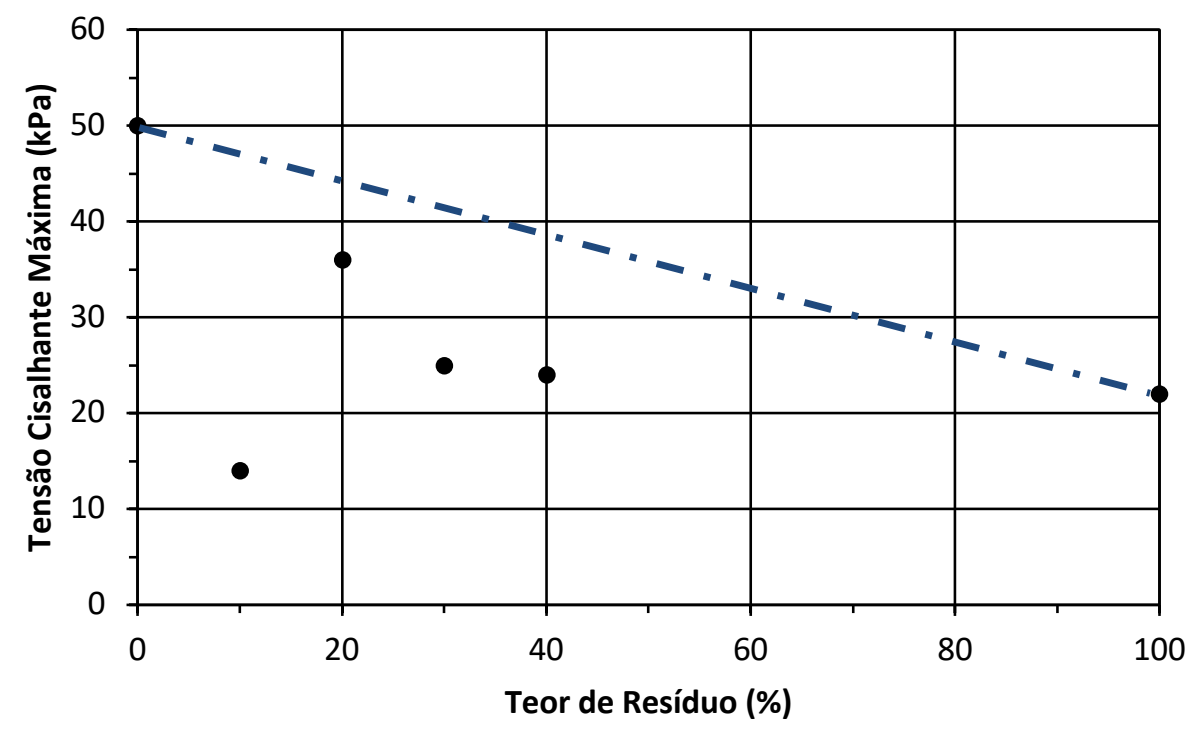

Figura 7: Tensão de cisalhamento máxima versus teor de resíduo para a tensão normal de 50 kPa.

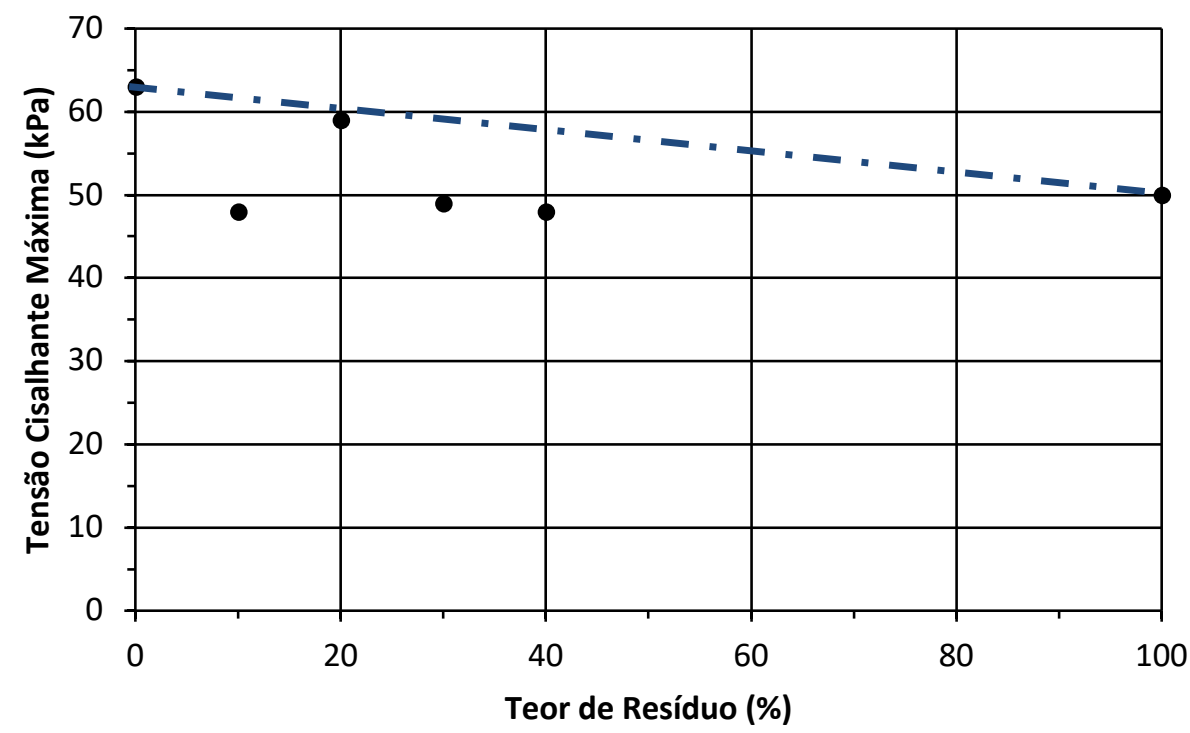

Figura 8: Tensão de cisalhamento máxima versus teor de resíduo para a tensão normal de 100 kPa. 


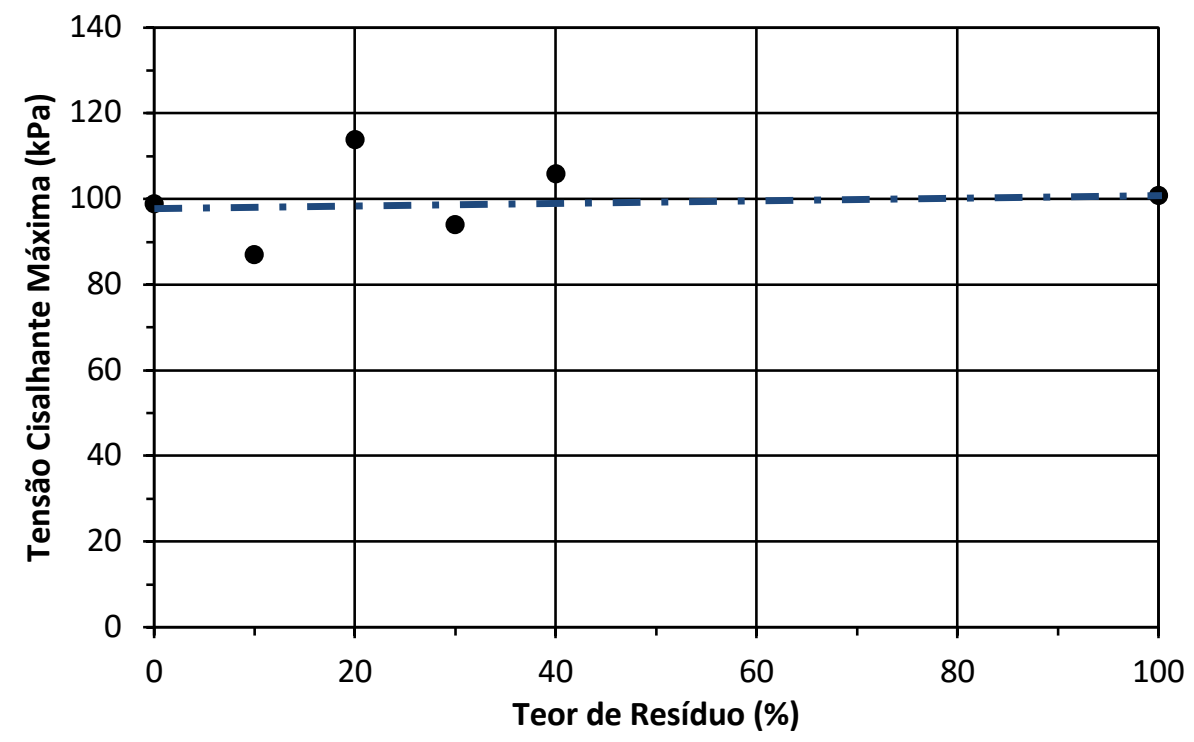

Figura 9: Tensão de cisalhamento máxima versus teor de resíduo para a tensão normal de 200 kPa.

Na Figura 10 estão apresentadas as envoltórias de resistência ao cisalhamento para a condição de ruptura, conforme o critério de Mohr-Coulomb, e na Tabela 4 os correspondentes valores do intercepto de coesão (c), do ângulo de atrito interno $(\phi)$ e do coeficiente de determinação $\left(R^{2}\right)$ obtidos nos ajustes das envoltórias para as diferentes misturas. Todos os ajustes apresentaram $R^{2}$ igual ou superior a 0,99 .

Verifica-se na Figura 10 que a mistura com 20\% de resíduo apresentou a envoltória mais próxima em relação à do solo puro e maiores parâmetros de resistência ao cisalhamento em relação às demais misturas analisadas.

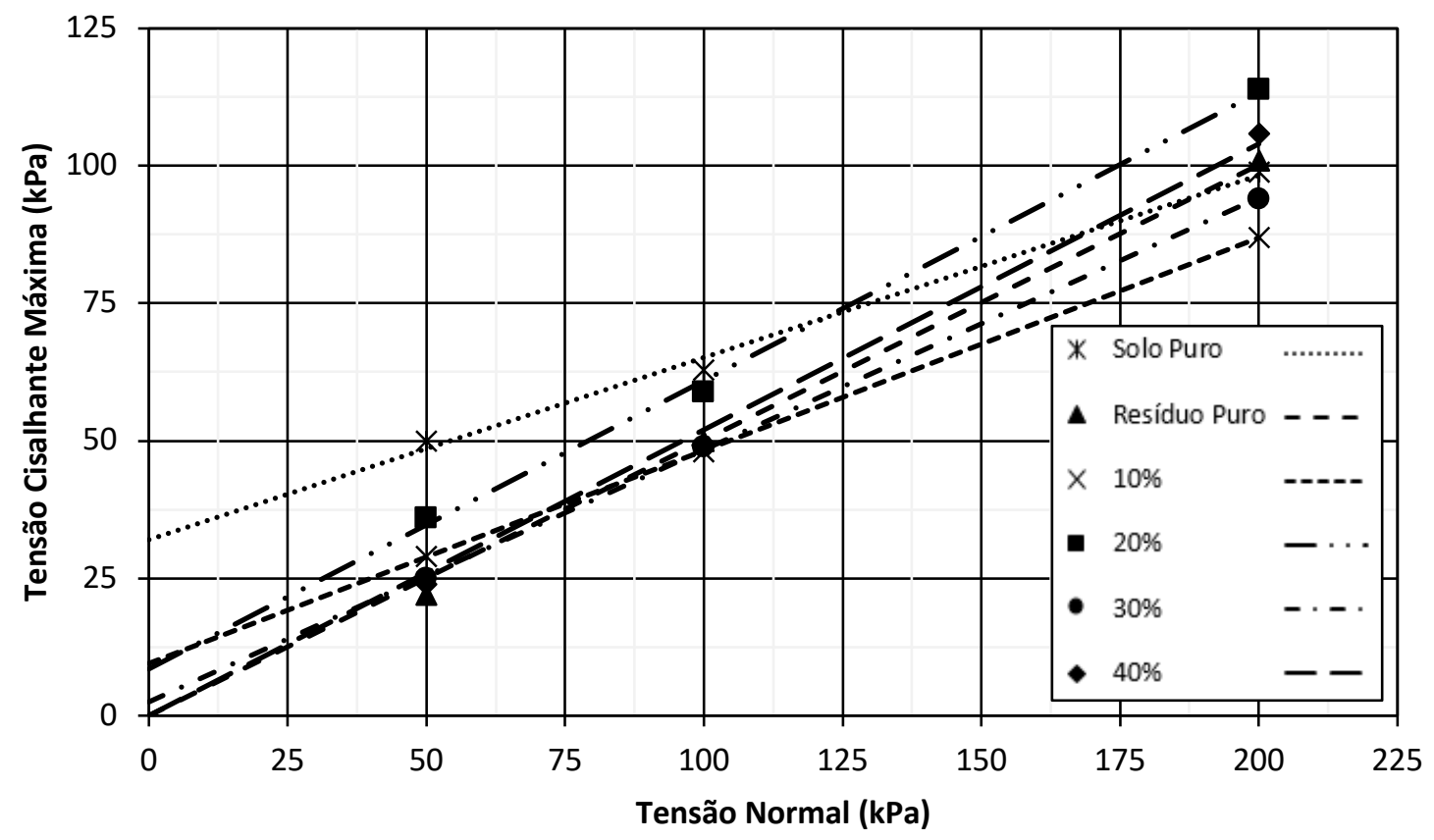

Figura 10: Envoltórias de ruptura para todas as condições ensaiadas. 
Tabela 4: Síntese dos parâmetros de resistência para o solo puro, resíduo puro e misturas.

\begin{tabular}{cccc}
\hline Teor de resíduo (\%) & Coesão $(\mathbf{k P a})$ & Ângulo de atrito interno $\left(^{\circ}\right)$ & $\mathbf{R}^{\mathbf{2}}$ \\
\hline 0 & 32,0 & 18,3 & 0,99 \\
10 & 9,5 & 21,2 & 1,00 \\
20 & 8,5 & 27,7 & 0,99 \\
30 & 2,5 & 24,6 & 0,99 \\
40 & - & 27,9 & 0,99 \\
100 & - & 26,6 & 0,99 \\
\hline
\end{tabular}

Nas Figuras 11 e 12 é possível observar a variação dos valores de coesão e do ângulo de atrito, respectivamente, com o aumento do teor de resíduo nas misturas. Na Figura 11 verifica-se que os valores de coesão das misturas foram inferiores ao solo puro e conforme houve o acréscimo de resíduo o parâmetro obteve redução, atingindo um valor nulo. Estes valores eram previstos em virtude da composição do resíduo, que possui características de solos arenosos, os quais apresentam apenas coesão aparente. Em relação ao ângulo de atrito interno (Figura 12), em geral, houve uma tendência de aumento com o acréscimo do teor resíduo nas misturas em relação ao solo puro, também devido às características de material granular das microesferas de vidro.

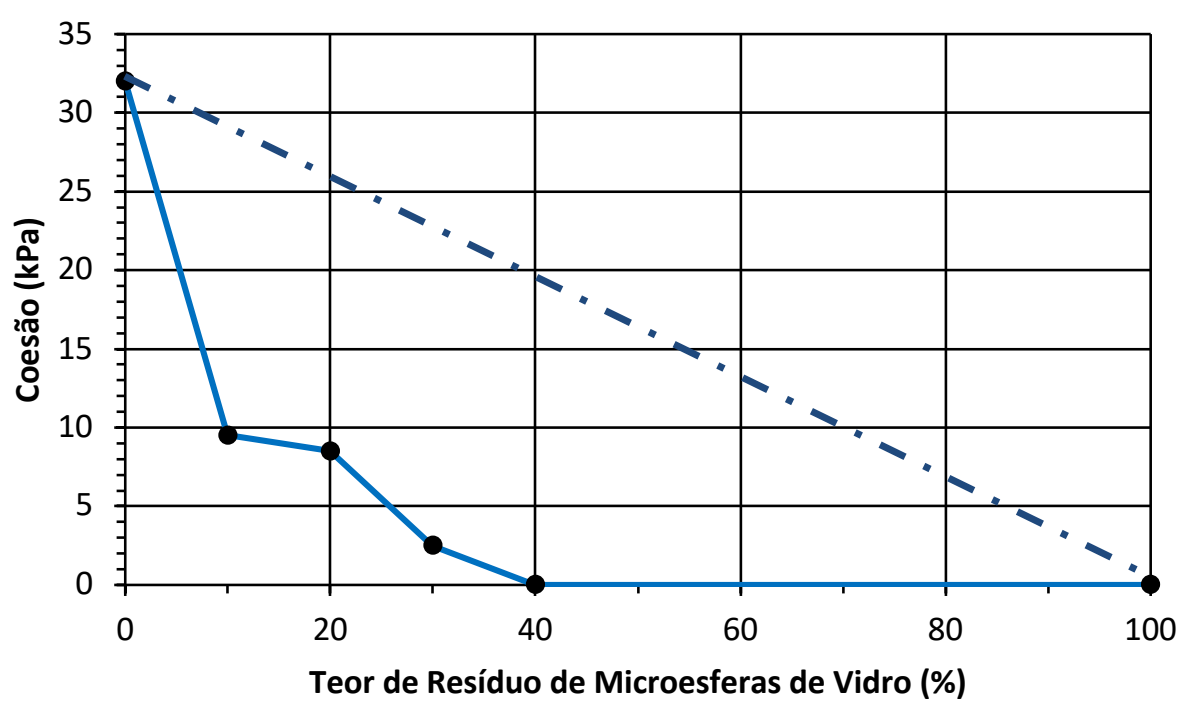

Figura 11: Relação entre o teor de resíduo e coesão. 


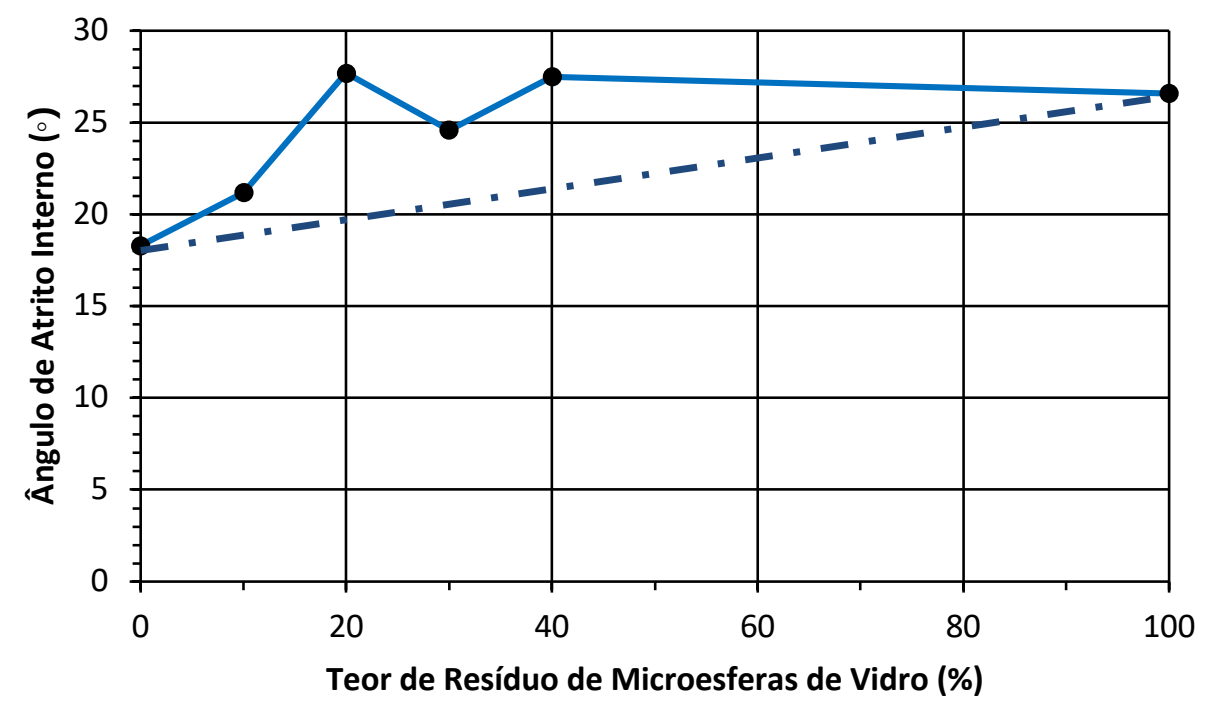

Figura 12: Relação entre o teor de resíduo e ângulo de atrito interno.

Ensaio de expansão e de Índice de Suporte Califórnia (ISC)

Na Figura 13 é possível observar o comportamento expansivo de todos os copos de prova estudados. Nota-se que conforme se dá a adição de resíduo ao solo, este fica mais suscetível a expandir. O resíduo puro apresentou a maior expansão, com um valor de 0,59\%. Já entre as misturas o teor de resíduo de $40 \%$ mostrou-se mais expansivo, com o valor de $0,43 \%$.

Por meio do ensaio de expansão também já é possível prever que a capacidade de suporte dos materiais será reduzida, pois os solos mais resistentes tendem a apresentar índices de expansão menores.

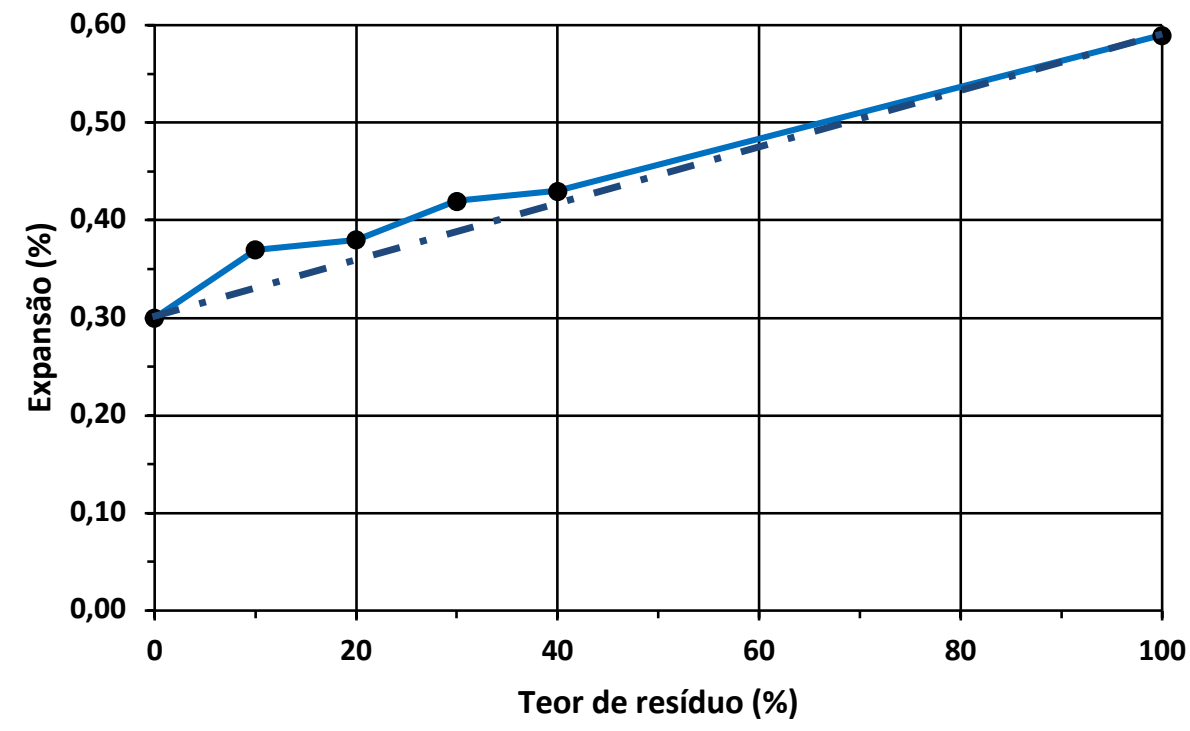

Figura 13: Expansão apresentada pelo solo puro, pelo resíduo puro e as misturas solo-resíduo. 
Os valores de Índice de Suporte Califórnia também apresentaram decréscimo com o aumento da concentração de resíduo de microesferas de vidro, conforme pode-se visualizar na Figura 14. Com a faixa de valores obtidos, o que se pode concluir é que o incremento de resíduos ao solo, mesmo reduzindo o ISC, favorece o emprego das misturas contendo 10 e $20 \%$ de resíduo em camadas executivas de pavimentos, tendo em vista que a regulamentação DNIT ES 137 (2010) sugere que o Índice de Suporte Califórnia deve ser igual ou superior a 6 \% para que o composto seja empregado na regularização do subleito de pavimentos. Os valores de expansão determinados no ensaio atendem nos critérios da referência normativa, a qual sugere que a expansão não deve superar $2 \%$.

Em geral, também se sugere que as misturas sejam utilizadas para fins de aterros executados por meio de terraplanagem. Segundo o referencial normativo DNIT ES 108 (2009) para o emprego de compostos neste tipo de obra, requisita-se que o ISC seja superior a $2 \%$ e a expansão não ultrapasse $4 \%$.

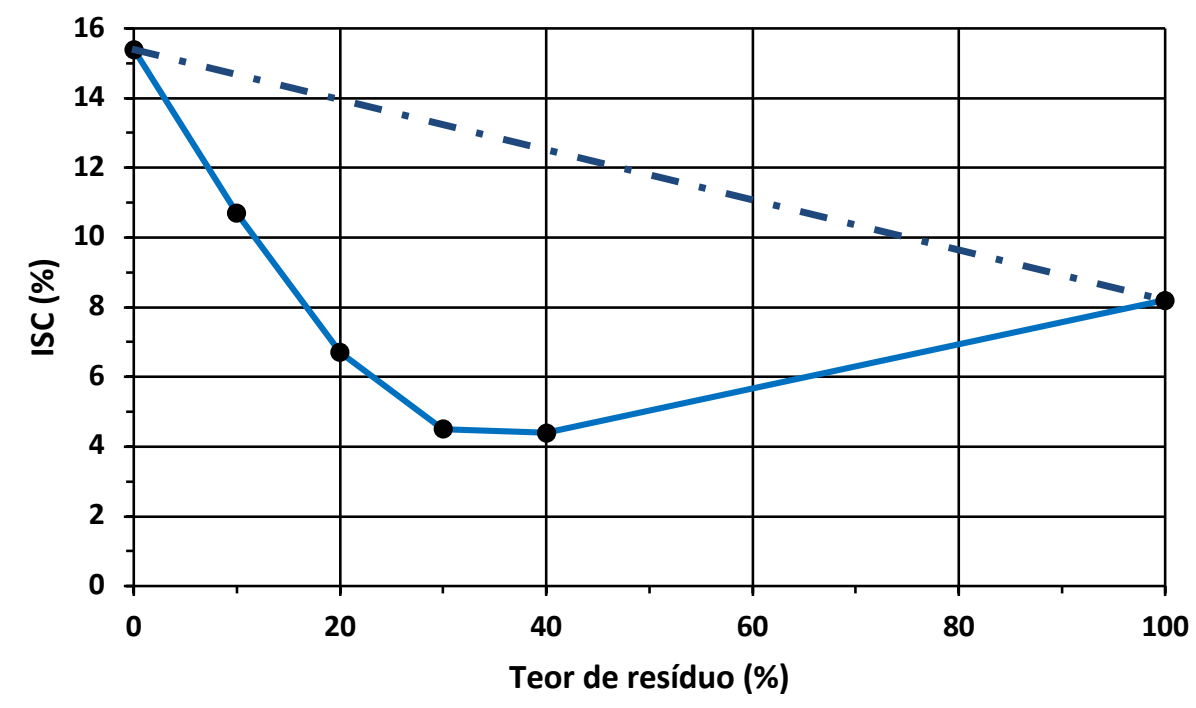

Fig. 14 - Índice de Suporte Califórnia determinado para todas as condições ensaiadas.

\section{CONSIDERAÇÕES FINAIS}

Destaca-se que muitos fatores devem ser analisados para a escolha de materiais residuais de processos industriais para uso em obras geotécnicas e, sempre que possível, é necessário programar uma série de ensaios de caracterização química e geotécnica prévia tanto do resíduo, quanto das misturas que se pretende propor. Outro fator que influencia nos resultados é a escolha do solo que será objeto do estudo. No presente trabalho foi utilizado um solo residual de basalto encontrado em uma vasta área da região Sul do Brasil e resíduos de microesferas de vidro.

No ensaio de compactação pode-se observar a efetiva influência que o resíduo exerceu sobre o solo, pois em todas as misturas analisadas foram obtidos teores de umidade ótimos inferiores e valores de massa específica seca máxima maiores em relação ao solo puro. Essa contribuição pode ser considerada positiva, pois para o emprego em algumas obras de infraestrutura pode favorecer algumas propriedades geotécnicas do solo. 
Em relação aos ensaios de cisalhamento direto, o comportamento dos corpos de prova foi bastante semelhante visto que as tensões máximas de cisalhamento foram registradas, na maioria dos casos, durante o descolamento horizontal de 3 a $4 \mathrm{~mm}$. Pode-se constatar também que com o acréscimo de resíduo, as curvas de tensão cisalhante versus deformação horizontal adquiriram características apresentadas por areias fofas, nas quais é possível analisar um lento acréscimo de tensão axial em conjunto com a deformação. A deformação vertical se deu predominantemente por meio da contração de todas as amostras.

Os valores de ângulo de atrito mais elevados das misturas podem ser relacionados com a melhor distribuição granulométrica que cada uma adquiriu, o que pressupõe um melhor entrosamento entre elas. Este resultado pode ser considerado como positivo, pois o ângulo de atrito reflete diretamente na resistência do solo. No caso da coesão, a redução dos valores também já era esperada conforme a adição do resíduo, pois as misturas adquiriram gradativamente características semelhantes às de solos arenosos, os quais não são coesivos. A mistura com teor de resíduos de 20\% apresentou a envoltória de resistência mais próxima à do solo puro.

$\mathrm{Na}$ determinação do ISC, constatou-se que as misturas de 10 e $20 \%$, embora tenham apresentado valores baixos do índice, ainda estão propensas à aplicação na regularização de subleitos de pavimentos.

Mediante a resistência apurada para as misturas e o bom desempenho observado no ensaio de compactação, sugere-se também que estas sejam avaliadas para uso em projetos de recuperação de áreas degradadas. Nestes casos, dependendo da finalidade da área a ser recuperada, faz-se necessário o uso de materiais em misturas com o solo para assegurar a boa compactação dos aterros, por isso os resíduos de microesferas, se bem compactados e aplicados na dosagem correta, poderiam auxiliar na execução deste tipo de obra de engenharia.

\section{REFERÊNCIAS BIBLIOGRÁFICAS}

Ahmed, A.; Ugai, K. \& Kamei, T. (2011). Investigation of recycled gypsum in conjunction with waste plastic trays for ground improvement. Construction and Building Materials, v. 25, p. 208-217.

Associação Brasileira de Normas Técnicas (1984). NBR 6508: Grãos de solos que passam na peneira de 4,8 mm - Determinação da massa específica. Rio de Janeiro.

Associação Brasileira de Normas Técnicas (2004). NBR 10004: Resíduos Sólidos - Classificação. Rio de Janeiro.

Associação Brasileira de Normas Técnicas (1984). NBR 6459: Solo - Determinação do limite de liquidez. Rio de Janeiro.

Associação Brasileira de Normas Técnicas (1984). NBR 7180: Solo - Determinação do limite de plasticidade. Rio de Janeiro. 
Associação Brasileira de Normas Técnicas (1986). NBR 9895: Solo - Índice de Suporte Califórnia. Rio de Janeiro.

Departamento Nacional de Estradas de Rodagem (1994). DNER - ME 058: Microesferas de vidro retrorrefletivas para a demarcação viária - determinação da granulometria. Rio de Janeiro - RJ.

Departamento Nacional de Infraestrutura de Transportes (2009). DNIT - ES 108: Terraplanagem Aterros. Rio de Janeiro - RJ.

Departamento Nacional de Infraestrutura de Transportes (2010). DNIT - ES 137: Pavimentação Regularização do subleito. Rio de Janeiro - RJ.

Diemer, F.; Specht, L. P.; Strauss, D. A. \& Pozzobon, C. E. (2008). Propriedades geotécnicas do solo residual de basalto da região de ljuí/RS. Teoria e Prática da Engenharia Civil, n.12, p. 25-36, out.

Ferreira, S. R. M.; Paiva, S. C.; Morais, J. J. O. \& Viana, R. B. (2017). Avaliação da expansão de um solo do município de Paulista-PE melhorado com cal. Revista Matéria, Suplemento. Rio de Janeiro, 2017, vol. 22.

Kafodya, I. \& Okonta, F. (2018). Effects of natural fiber inclusions and pre-compression on the strength properties of lime-fly ash stabilised soil. Construction and Building Materials, v. 170, p. 737-746.

Machado, C. C. \& Portugal, C. R. M. (2012). Comportamento geotécnico de misturas granulometricas de solo-grits. Revista Árvore, v. 36, n. 3, p.519-526.

Malanconi, M. (2013). Considerações sobre misturas de solos tropicais estabilizados quimicamente para uso como camada de pavimento urbano. Dissertação (Mestrado) - Universidade Federal de São Carlos.

Menegotto, M. L.; Bandeira, F. O.; Sartori, L. \& Morais, M. (2016). Caracterização geotécnica preliminar do solo da Área Experimental da UFFS - Campus Chapecó. In: Congresso Brasileiro de Mecânica dos Solos e Engenharia Geotécnica, 18. 2016, Belo Horizonte - MG. Anais... São Paulo: ABMS.

Moreira, E. B. (2018). Comportamento mecânico de um solo argiloso misturado com resíduos de construção e demolição para utilização em pavimentação. Dissertação (Mestrado) Universidade Tecnológica Federal do Paraná, Programa de Pós-Graduação em Engenharia Civil. Curitiba.

Scheibe, L. F. (1986). A geologia de Santa Catarina: sinopse provisória. Geosul, Vol. 1, n. 1, p. 7-38.

Silva, F. B. S. (2016). Avaliação de misturas de solo de resíduo de polimento de porcelanato para emprego em obras rodoviárias. Dissertação (Mestrado) - Universidade Federal do Rio Grande do Norte, Centro de Tecnologia, Programa de Pós-Graduação em Engenharia Civil. Natal, RN.

Suluguru, A. K.; Jayatheja, M.; Kar, A.; GuhaRay, A.; Surana, S. R. \& James, N. (2017). Experimental studies on the microstructural, physical and chemical characteristics of building derived 
materials to assess their suitability in ground improvement. Construction and Building Materials, v. 156, p. 921-932.

Wei, I.; Chai, S. X.; Zhang, H. Y. \& Shi, Q. (2018). Mechanical properties of soil reinforced with both lime and four kinds of fiber. Construction and Building Materials, v. 172, p. 300-308.

Zornberg, J. G.; Cabral, A. R. \& Viratjandr, C. (2004). Behaviour of tire shred - sand mixtures. Canadian Geotechnical Journal, n. 41, p. 227-241. 